\title{
The Indian Mackerel Aggregation Areas in Relation to Their Oceanographic Conditions
}

(Perkaitan Kawasan Pengumpulan Ikan Kembung India dan Keadaan Oseanografi)

\author{
YENY NADIRA, K., MUSTAPHA, M.A.* \& GHAFFAR, M.A.
}

\begin{abstract}
In order to determine the favourable oceanographic conditions which influence fish aggregation areas, the integration of remote sensing and GIS technique was applied. This paper aims to classify the spatial distribution and abundance of R. kanagurta in the South China Seas (SCS) using principal component analysis (PCA) and cluster analysis (CA). Remotely-sensed satellite oceanographic data of chlorophyll-a concentration (chl-a), sea surface temperature (SST) and sea surface height (SSH) together with high catch fish data were used to characterize seasonal abundance of the R. kanagurta. PCA identified two principal components that had eigenvalues $>1$ (PC1 and PC2) which accounted for $59.3 \%$ of the cumulative variance. Factor loading in the PCA proved that all environmental variables used in this study; chl-a (PC1), SSH and SST (PC2) had influenced the CPUE of R. kanagurta. Using CA, two clusters of CPUE abundance were identified. In cluster 1 , an average CPUE of $350.7 \mathrm{~kg} / \mathrm{m}^{3}$ with highest catch were recorded in January, April, May, July and October. Meanwhile, in cluster 2, an average CPUE of $1033.9 \mathrm{~kg} / \mathrm{m}^{3}$ with highest catch were recorded in April, May, September and October. Preferred range for fish aggregations showed SST, SSH and chl-a were observed in between 29-31 ${ }^{\circ} \mathrm{C}, 1.12-1.28 \mathrm{~m}$ and 0.24-0.42 $\mathrm{mg} / \mathrm{m}^{3}$, respectively. Binary habitat suitability index was used to model the potential aggregation areas. The highest potential fish aggregations areas of $\mathrm{R}$. kanagurta were found located along the coast of Peninsular Malaysia in early and late Southwest monsoon (at accuracy of $83.68 \%$ with kappa of 0.7).
\end{abstract}

Keywords: Chlorophyll-a; fish aggregation areas; Rastrelliger kanagurta; sea surface height; sea surface temperature

\section{ABSTRAK}

Integrasi antara data penderiaan jauh dan teknik GIS diaplikasi bagi menentukan keadaan oseanografi yang mempengaruhi kawasan pengumpulan ikan. Objektif dalam kajian ini adalah untuk mengelaskan taburan reruang dan kelimpahan R. kanagurta di Laut China Selatan menggunakan analisis komponen prinsipal (PCA) dan analisis kelompok (CA) serta mengenal pasti perhubungan antara taburan ikan dengan keadaan persekitaran. Hubungan antara data taburan klorofil-a (chl-a), suhu permukaan laut (SST) dan ketinggian permukaan laut (SSH) daripada satelit penderiaan jauh serta taburan tangkapan R. kanagurta digunakan untuk mengenal pasti hubungan taburan musiman ikan pelagik. PCA mengenal pasti dua komponen prinsipal yang mempunyai nilai eigen $>1$ ( PCl dan PC2) dengan nilai peratus kumulatif varians adalah 59.3\%. Faktor penentuan dalam komponen prinsipal menunjukkan bahawa parameter persekitaran mempengaruhi data tangkapan ikan. CA menunjukkan dua kelompok tangkapan ikan dengan kelompok 1, nilai purata tangkapan ikan sebanyak $350.7 \mathrm{~kg} / \mathrm{m}^{3}$ dengan catatan tangkapan ikan tertinggi pada bulan Januari, April, Mei, Julai, September dan Oktober. Manakala, di dalam kelompok 2, nilai purata tangkapan ikan sebanyak $1033.9 \mathrm{~kg} / \mathrm{m}^{3}$ dengan catatan tangkapan ikan tertinggi pada bulan April, Mei, September dan Oktober. Julat kesesusaian cerapan pengumpulan ikan bagi SST, SSH dan chl-a didapati pada suhu 29-3 $1^{\circ} \mathrm{C}, 1.12-1.28 \mathrm{~m}$ dan 0.24-0.42 mg/m $\mathrm{m}^{3}$. Kawasan berpotensi bagi pengumpulan $\mathrm{R}$. kanagurta yang dimodel menggunakan indeks kesesuaian habitat mendapati kawasan pengumpulan R. kanagurta paling berpotensi terletak di sepanjang perairan pantai Semenanjung Malaysia pada permulaan dan akhir musim monsun barat daya (pada ketepatan $83.68 \%$ dengan nilai kappa 0.7 ).

Kata kunci: Kawasan pengumpulan ikan; ketinggian permukaan laut; klorofil-a; Rastrelliger kanagurta; suhu permukaan laut

\section{INTRODUCTION}

The Indian mackerel (Rastrelliger kanagurta) is an epipelagic scombrid that is widespread across the northwest and east of Peninsular Malaysia, Sabah and Sarawak (Mansor 1989). It is one of the most commercially important small pelagic fishery resources (Mansor et al. 1996). This species are fast-swimmers and schools in large aggregations (Collette \& Russo 1984), migrates seasonally and geographically in relation to the annual cycles of ocean productivity, reproductive cycles, ocean currents and circulation (Skjoldal 2004). Due to the complexity of the spatial structure of distribution of this pelagic species, it is difficult for fishermen to determine its fishing grounds. However, this species tends to aggregate 
in relation to their physical and biological indicators of the ocean environment. According to Solanki et al. (2005) physical processes in the upper ocean influence biological processes and ultimately determine the distribution of pelagic fish. Thus, it is possible to describe and understand the relationship between oceanographic conditions and biological interaction which affects and influences the dynamics of pelagic stocks (Shaari \& Mustapha 2018).

Previous studies have shown that the distribution and abundance of the Indian mackerel is greatly influenced by oceanographic conditions such as sea surface temperature (SST) and chlorophyll- $a$ concentration (chl- $a$ ). SST is one of the most common oceanographic variables in indicating the changes and variability of the monsoon (Nurdin et al. 2017a) and it is widely used in combination with chl- $a$ to explain fish distribution and abundance (Chassot et al. 2011). Meanwhile, sea surface height (SSH) measurements which also influence fish aggregation provide insights into ocean current movement (Zagaglia et al. 2004). Hence, it is predicted that these oceanographic conditions may influence the abundance and distribution of the Indian mackerel.

Generation of high spatial and temporal remote sensing data integrated with geographical information system (GIS) has made it possible for oceanographic parameters observation. GIS also extensively used in marine fisheries studies especially in determination of relationship between fish population dynamics and environmental factors (Nishida et al. 1999; Pena et al. 1999; Zheng et al. 2001). Thus, integration of satellite data, GIS and statistical analysis, combined with in-situ observations related to fisheries abundance are most effective ways to manage fisheries at sustainable levels (Wilson 2011). This paper aims to classify the spatial distribution and abundance of the Indian mackerel in the South China Seas (SCS) using principal component analysis (PCA) and cluster analysis (CA) and to identify relationship of distribution with local environmental conditions.

\section{MATERIALS AND METHODS}

\section{STUDY AREA}

This study analysed the R.kanagurta catches using purse seine conducted by Southeast Asian Fisheries Development Center (SEAFDEC) at the east coast of Peninsular Malaysia's Exclusive Economic Zone (EEZ) (Figure 1). The area of the east coast of Peninsular Malaysia (EEZ) is about 130,000 $\mathrm{km}^{2}$ which covers from $1^{\circ} 14.047^{\prime}$ to $7^{\circ} 48.92^{\prime} \mathrm{N}$ and $102^{\circ} 5.03^{\prime}$ to $105^{\circ} 48.77^{\prime} \mathrm{E}$ (Mohsin \& Mohamed 1988). The climate in the area is controlled by the SCS monsoon due to its location at the tropical marginal sea of the Southeast Asia (Fang \& Fang 1998). The monsoon systems in SCS are influenced by two main monsoons, namely the Southwest Monsoon (SWM) from May to August and Northeast Monsoon (NEM) from November to February (Suhaila \& Jemain 2009). There are also two inter-monsoon transitions in between the monsoon systems; inter-monsoon transition from March to April and inter-monsoon transition from September to October (MMD 2016; Yahaya et al. 2016).

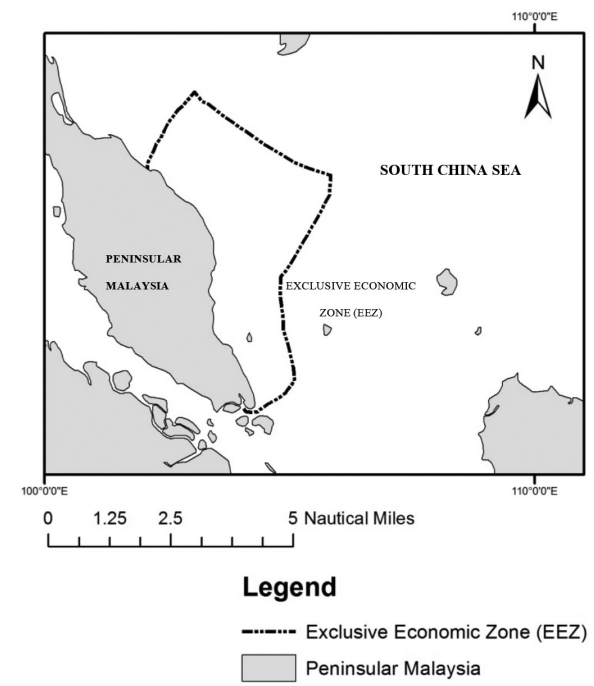

FIGURE 1. The Exclusive Economic Zone (EEZ) area of east coast of Peninsular Malaysia in the South China Sea where fishing of R. kanagurta are conducted

\section{FISHERIES DATA}

The Indian mackerel fisheries data from 2008 until 2010 were used in this study. The data consisted of total 4281 fishing locations with total catch per unit effort $\left(\mathrm{kg} / \mathrm{m}^{3}\right)$. Based on previous studies (Andrade \& Garcia 1999; Zainuddin et al. 2008) in order to discern catch data, we separated the fishery data into three categories: Null catches, positive catches and high catches. The value of CPUEs greater than $127 \mathrm{~kg} / \mathrm{m}^{3}$ represented the lower limit of the upper quartile of CPUEs greater than zero. We divided the CPUE data into: cases with CPUE equal to zero - 'null catches'; cases with CPUE greater than zero but lower than $127 \mathrm{~kg} / \mathrm{m}^{3}$ - 'positive catches'; and cases with CPUE greater than $127 \mathrm{~kg} / \mathrm{m}^{3}$ - 'high catches'. In this study only the 'high catches' data were used. A total of 158 'high catches' data were analysed.

\section{ENVIRONMENTAL DATA}

Remotely-sensed environmental data of chl- $a$, SST \& SSH were used in this study. Daily MODIS level 1 SST and chl- $a$ dataset from the Ocean Color website at 1 $\mathrm{km}^{2}$ spatial resolution were downloaded from 2008 until 2010. Data were processed using SeaWiFS Data Analysis System (SeaDAS) version 6.1 software. Generated Level 3 product was subset from the images to the study area at geographical extent of $1^{\circ}$ to $8^{\circ} \mathrm{N}$ and $102^{\circ}$ to $106^{\circ} \mathrm{E}$ using ERDAS Imagine version 10.0 software. The absolute daily SSH data were obtained from Archiving, Validation and Interpretation of Satellite Oceanographic Data (AVISO) which was downloaded from NOAA CoastWatch at 0.25 degrees spatial resolution in both longitude and latitude. Due to the different spatial resolutions, interpolation is 
applied for the enhancement of the SSH spatial resolution using GIS tools. Daily values of chl-a, SST and SSH were extracted from each pixel corresponding to the location of fishing activities using spatial analyst of ArcGIS 10.0.

\section{DATA ANALYSIS}

PCA is one of several statistical tools that are available to reduce the dimensionality of a data set. PCA was conducted to represent the patterns encoding the highest variance in the fish catch data set. To run the PCA a matrix of correlations of fishery CPUE as dependent variables and environmental variables studied (chl- $a$, SST and SSH) as independent variables was constructed. A principal component is a normalized linear combination of the original predictors in a data set. The principal component can be written as:

$$
Z^{1}=\Phi^{11} X^{1}+\Phi^{21} X^{2}+\Phi^{31} X^{3}+\ldots .+\Phi^{1} X^{p}
$$

where $\mathrm{Z}^{1}$ is first principal component; $\Phi^{1}$ is the loading vector comprising of loadings $\left(\Phi^{1}, \Phi^{2}\right.$..) of first principal component. The loadings are constrained to a sum of square equals to 1 . This is because large magnitude of loadings may lead to large variance. It also defines the direction of the principal component $\left(\mathrm{Z}^{1}\right)$ along which data varies the most. It results in a line in $p$ dimensional space which is closest to the $n$ observations. Closeness is measured using average squared euclidean distance. Meanwhile, $\mathrm{X}^{1}$...X are normalized predictors. Normalized predictors have mean equals to zero and standard deviation equals to one. Kaiser-Guttman (Guttman 1954) and broken-stick criterion (Frontier 1976; Legendre \& Legendre 1998) were applied as stopping rules for determining the number of principal component. These rules are based on average test statistic values. Eigenvalues or eigenvectors that is larger than the average value expected under the null is used to assess the relative interpretability of the ordination results. PCA that has eigenvalues more than 1 is considered to represent significant assemblages (Jackson 1993; Jolliffe 1986).

Meanwhile, CA was used to classify the object into homogenous groups. CA of CPUE 'high catches' data were determined using hierarchical clustering. A hierarchical clustering algorithm represented below can be used to generate a partition by minimizing the sum of squared errors;

$$
J_{k}=\sum_{K=1}^{K} \sum_{i \in C k}\left(x_{i}-m_{k}\right)^{2}
$$

where $(\mathrm{x} 1, \cdots, \mathrm{xn})=\mathrm{X}$ is the data matrix and $\mathrm{m}_{\mathrm{k}}=\Sigma_{i \in \mathrm{Ck}}$ $\mathrm{x}_{\mathrm{i}} / n_{k}$ is the centroid of cluster $\mathrm{C}_{\mathrm{k}}$ and $n_{k}$ is the number of points in $\mathrm{C}_{\mathrm{k}}$ (Bradley \& Fayyad 1998; Grim et al. 1998; Moore 1998). Analyses of PCA and CA were conducted using R software (V3.5).

Relationship between the environmental parameters and CPUE was determined using frequency analysis (FA). FA was used to determine preferred ranges of the variables from the frequency distribution. Binary habitat suitability model was then constructed using the $R$. kanagurta preferred ranges in GIS to identify species aggregation areas. Accuracy assessment was conducted on the predicted aggregation area was carried out using Kappa Statistics. Kappa statistics characterized the degree of matching between reference data set and classification. It was conducted on the predicted aggregation areas and validated using independent catch data (Vasconcelos et al. 2013).

\section{RESULTS}

Based on Kaiser-Guttman and broken stick model criterion, when using correlation matrices, population components having eigenvalues more than 1 summarize shared variation and should be retained. In this study, PCA identified the first two principal components of having eigenvalues more than 1 (PC1 \& PC2) which explained $59.3 \%$ of the cumulative variation. PC1 and PC2 accounted variability of $33.3 \%$ and $26 \%$, respectively (Table 1).

TABLE 1. Eigenvalues, percentage of variance and cumulative variance of each principal component in terms of average CPUE data

\begin{tabular}{cccc}
\hline $\begin{array}{c}\text { Principal } \\
\text { component }\end{array}$ & Eigenvalue & $\begin{array}{c}\text { Variance } \\
(\%)\end{array}$ & $\begin{array}{c}\text { Cumulative } \\
\text { variance }(\%)\end{array}$ \\
\hline PC1 & 1.15 & 33.3 & 33.3 \\
PC2 & 1.02 & 26.0 & 59.3 \\
PC3 & 0.93 & 23.3 & 82.6 \\
PC4 & 0.84 & 17.4 & 100.0 \\
\hline
\end{tabular}

The highest factor loading value determines which environmental variables influence the principal component the most. Factor loadings of the four variables in the first two components of the PCA indicated that the first principal component had large associations with chl- $a$. Meanwhile, the second component indicated large associations with SSH and SST (Table 2).

TABLE 2. Loadings of the first two principal components (PC1 and PC2) on the average of CPUE data in relation to its oceanographic variables

\begin{tabular}{cll}
\hline Variable & PC1 & PC2 \\
\hline Chl-a & $-0.63 *$ & -0.02 \\
SST & -0.46 & $0.69 *$ \\
SSH & -0.44 & $-0.72 *$ \\
CPUE & -0.44 & 0.02 \\
\hline
\end{tabular}

(*) represent highest values of factor loading that influences the principal component the most

CA of the first two principal components defined two cluster of CPUE abundance. Cluster 1 indicated average CPUE of $350.7 \mathrm{~kg} / \mathrm{m}^{3}$; meanwhile, cluster 2 indicated average CPUE of $1033.9 \mathrm{~kg} / \mathrm{m}^{3}$. For cluster 1 , highest CPUE catch above average of $350.7 \mathrm{~kg} / \mathrm{m}^{3}$ were recorded in January, 
April, May, July and October. Meanwhile for cluster 2, highest CPUE catch above average of $1033.9 \mathrm{~kg} / \mathrm{m}^{3}$ were recorded in April, May, September and October (Figure 2).

PCA indicated that the environmental variables used in this study influenced the CPUE. CA indicated variability in seasonal patterns of fish abundance which showed that variability in oceanographic conditions influenced fish aggregations. From the CA results, the highest CPUE value occurred in early SWM and late SWM.

$R$. kanagurta potential aggregation areas were constructed using FA according to the oceanographic parameters preferred ranges of SST, SSH and chl- $a$. Based on the FA result, high catch of $R$. kanagurta occurred at chl- $a$ range of $0.24-0.42 \mathrm{mg} / \mathrm{m}^{3}$, SST range of $29-30^{\circ} \mathrm{C}$ and $\mathrm{SSH}$ range of $1.12-1.28 \mathrm{~m}$. Figure 3 indicates that, most suitable potential of $R$. kanagurta aggregation areas in (a) May and (b) October were more distributed along the coast of Peninsular Malaysia. In comparison during (c) November and (d) February, which the potential fish aggregation areas were less distributed. The prediction map of $R$. kanagurta aggregation areas around the study area indicated accuracy at $83.68 \%$ with kappa of 0.7 .

\section{DISCUSSION}

\section{OCEANOGRAPHIC PARAMETERS AND} SEASONAL VARIABILITY

The PCA result indicated that all oceanographic parameters (SST, SSH and chl- $a$ ) used in this study influenced fish aggregations. It is well reported that SST is one of the most important oceanographic parameter in indicating the changes and variability of the monsoon and vital variable for detecting aggregation areas of Indian mackerel which are sensitive to the changes of temperature (Shaari \& Mustapha 2018). Meanwhile, chl- $a$ is known as an indicator of fish aggregation related to feeding habitat (Lanz et al. 2009). Areas of relatively stable temperature and high chlorophyll concentrations may attract feeding of pelagic species. SSHA is related to the changes in the depth of the thermocline and mesoscale variability (Polovina \& Howell 2005; Wyrtki 1961). According to Anon (1976), mackerel have a tendency to remain in the mixed layer, just above the thermocline where food availability is good.

The SCS is subjected to the seasonal monsoon seasons which affect the oceanographic conditions (MMD 2016). This variability thus influences the productivity of the fishing grounds. The oceanographic parameters such as chl- $a$, SST, currents and winds are the main processes that affect and influence the dynamics of pelagic fish distribution and abundance (Nurdin et al. 2014). In this study, CA showed that $R$. kanagurta high catch occurred in the early and late SWM. Occurrence of certain oceanographic processes is known to influence the productivity of an area. Processes of stratification and mixing during monsoons period is mainly influenced by sea surface wind, heat flux, river charges and density-driven and wind-driven currents (Akhir 2014).

The distribution of $R$. kanagurta from the suitability index was observed in the range of chl- $a$, SST and SSH were between $0.24-0.42 \mathrm{mg} / \mathrm{m}^{3}, 29-31^{\circ} \mathrm{C}$ and $1.12-1.28 \mathrm{~m}$, respectively. This was similar to the results of the study from Nurdin et al. (2017b) in the archipelagic waters of Spermonde, Indonesia where it was found that the highest fishing frequency of $R$. kanagurta was at chl- $a$ range of $0.24-0.30 \mathrm{mg} / \mathrm{m}^{3}$ and SST range of $29.6-30.2^{\circ} \mathrm{C}$. Based on Figure 2, cluster 1 showed that $R$. kanagurta catches were fairly high throughout the year $\left(>127 \mathrm{~kg} / \mathrm{m}^{3}\right)$ but highest catch was recorded in cluster 2 which were in April, May, September and October.

During the beginning of SWM, warmer surface area and weak surface wind contributes to development of stratification (Yanagi et al. 2001). Due to stratification, areas of relatively stable temperature and high chlorophyll- $a$ may attract feeding pelagic species (Chandran et al. 2009). Water stratification creates barrier of nutrient mixing between layers influencing the primary production for fish aggregation areas (Xian et al. 2012).

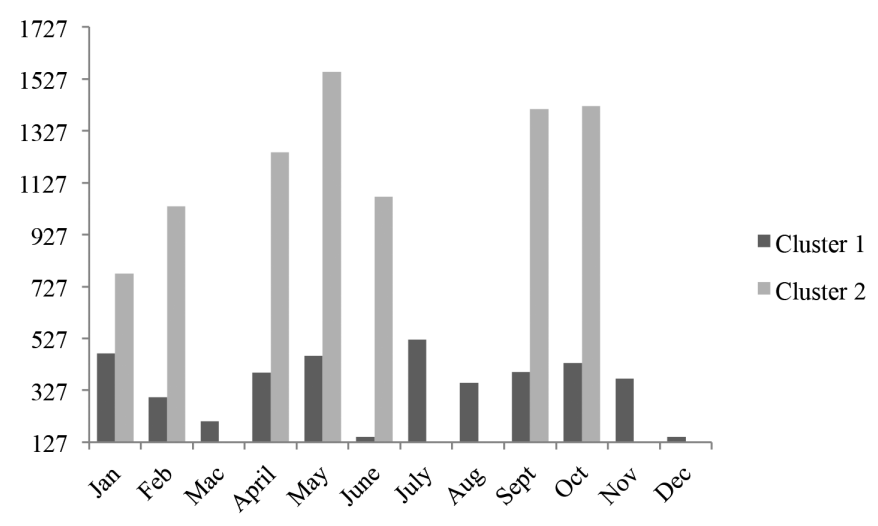

FIGURE 2. Average CPUE per month for cluster 1 with highest catch recorded in January, April, May, July, September and October. Average CPUE per month for cluster 2 with highest catch recorded in April, May, September and October 
Meanwhile, in late SwM, wind change and rain starts to occur. This generates mixing in the surface layer where occurrence of coastal upwelling supports phytoplankton growth (Susanto et al. 2006). Akhir et al. (2015) showed that occurrence of large coastal upwelling system along the coast during this season. The water is characterized by colder temperature, higher salinity and is rich in nutrient (Gambang et al. 2003). According to Shaari and Mustapha (2017), chl- $a$ concentration and distribution were related to availability of nutrients influenced by rainfall. These nutrients will fertilize the surface water which leads to high biological productivity. Good fishing grounds are typically found in these areas which have higher primary productivity and supports favorable fishing grounds (Zainuddin 2007).

\section{FISH SPECIES AGGREGATION AREAS}

The simple prediction map showed the most potential fish aggregation area during early and late SWM was detected along the coastal areas (Figure 3). It was observed that the predicted area was more distributed in May and October. Meanwhile, predicted maps represented by November and February which had lesser catch indicated smaller potential areas. This is due to lesser distribution of favorable environment for fish aggregation areas. Study by Shaari and Mustapha (2018) indicated highest catch of $R$. kanagurta was during October. Meanwhile, Gambang et al. (2003) also found small pelagic fishes of R. kanagurta closed to the shore and islands especially during the calm season (May - October).

The areas with high potential aggregation area were found along the coastal area and offshore of the EEZ with the range of chl $-a$ of $0.32-0.37 \mathrm{mg} / \mathrm{m}^{3}$, SST of $30.3-30.7^{\circ} \mathrm{C}$ and SSH of $1.13-1.17 \mathrm{~m}$ in April and May. Meanwhile, chl- $a$ of $0.31-0.32 \mathrm{mg} / \mathrm{m}^{3}$, SST of $29.1-29.7$ and SSH of $0.98-1.2 \mathrm{~m}$ in September and October (Table 3). Study by Yusop and Mustapha (2019) also showed the similar ranges. It also stated that chl- $a$ influenced $R$. kanagurta potential fishing ground during northeast and intermediate monsoon of October. Meanwhile, SST was found to influence the potential fishing grounds during southwest and intermediate monsoon period of April.

Chl- $a$ concentration is known as a very important oceanographic parameter in determining the productivity ocean upwelling (Xie et al. 2003). Rich nutrients often
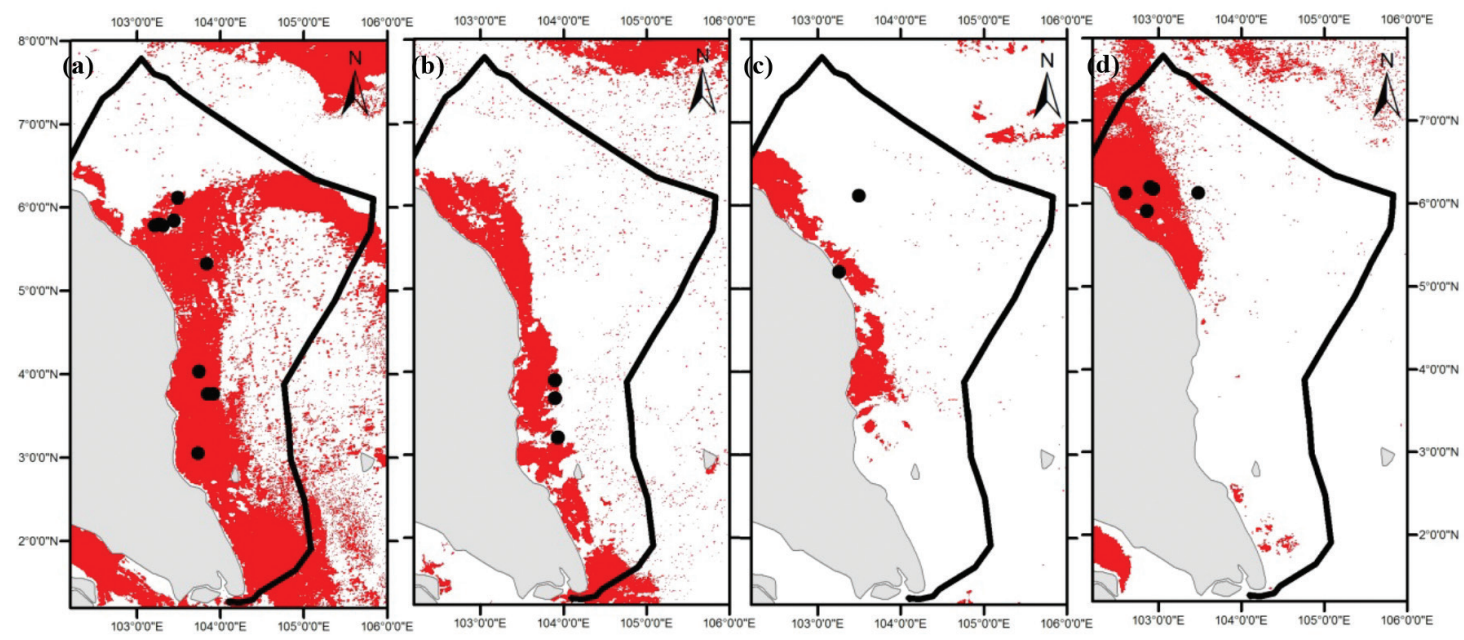

Legend
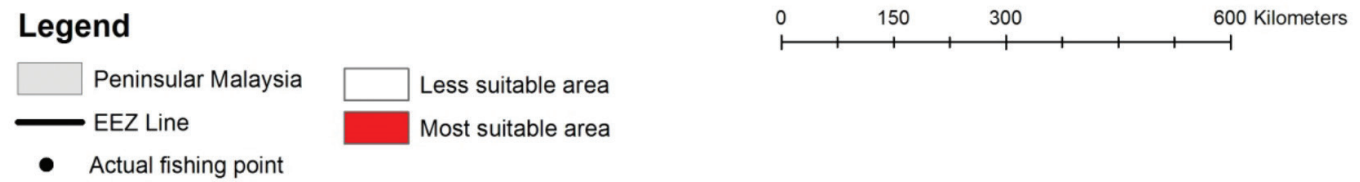

FIGURE 3. The environmental parameter (SST, SSH and chl- $a$ ) used to determined aggregation areas of R. kanagurta on (a) 16-23rd May 2008, (b) 7-14th October 2009, (c) 1-7th November 2008 and (d) 10-17th February 2010. Red areas indicated the most suitable aggregation areas according to the preferred ranges of environmental conditions for $R$. kanagurta.

Meanwhile, the white areas indicated the less suitable area for fish aggregations

TABLE 3. High CPUE catches of Indian mackerel in relation to oceanographic conditions in the EEZ of Peninsular Malaysia during April-May and Sept-October

\begin{tabular}{ccc}
\hline Oceanographic parameters & April -May & Sept -Oct \\
\hline Chl-a $\left(\mathrm{mg} / \mathrm{m}^{3}\right)$ & $0.32-0.37$ & $0.31-0.32$ \\
$\mathrm{SST}\left({ }^{\circ} \mathrm{C}\right)$ & $30.3-30.7$ & $29.1-29.7$ \\
$\mathrm{SSH}(\mathrm{m})$ & $1.13-1.17$ & $0.98-1.2$ \\
\hline
\end{tabular}


indicate an active biological activity which is mainly associated with the abundance and migratory patterns of the pelagic species (Solanki et al.2001). Meanwhile, SST is assumed to be an index of the physical environment, which influences phytoplankton growth (Tang \& Kawamura 2002) and controls the physiology of the living organisms such as spawning, aggregating and migrating period (Laevastu \& Hayes 1981). SSH is a proxy to determine the distribution of the fish species because of its relationship with geostrophic current. SSH is also related to the changes in the depth of the thermocline and mesoscale variability which can directly or indirectly impact the fishing grounds (Polovina \& Howell 2005; Rebert et al. 1985). Combination of these oceanographic parameters provides favorable environment for aggregation of the Indian mackerel.

\section{CONCLUSION}

PCA result showed that the environmental variables influenced the CPUE of $R$. kanagurta. Meanwhile, CA indicated variability in seasonal patterns of fish abundance which showed that variability in oceanographic conditions influenced fish aggregation areas. High distribution of $R$. kanagurta was related to chl- $a$ of $0.24-0.42 \mathrm{mg} / \mathrm{m}^{3}$, SST of $29-31^{\circ} \mathrm{C}$ and SSH of $1.12-1.28 \mathrm{~m}$. This study showed that variability in oceanographic conditions influenced aggregation areas of $R$. kanagurta spatially and temporally.

\section{ACKNOWLEDGEMENTS}

The authors would like to thank the NASA Goddard Space Flight Center for the MODIS-Aqua Level 1 data used in this study and SEAFDEC for supplying the fisheries data. This work has been supported by the Ministry of Science, Technology and Innovation Fund (04-01-02-SF0753).

\section{REFERENCES}

Akhir, M.F. 2014. Review of current circulation studies in the Southern South Shina Sea. Journal of Sustainability Science and Management 9(2): 21-30.

Akhir, M.F., Daryabor, F., Husain, M.L., Tangang, F. \& Qiao, F. 2015. Evidence of upwelling along Peninsular Malaysia during Southwest monsoon. Open Journal of Marine Science 5: 273-279.

Andrade, H.A. \& Garcia, C.A.E. 1999. Skipjack tuna fishery in relation to sea surface temperature off the southern Brazillian coast. Fisheries Oceanography 8(4): 245-254.

Anon. 1976. Plankton, fish eggs and larvae studies. UNDP/FAO Pelagic Fishery Project (IND/69/593). Progress Report No. 17. p. 27.

Bradley, P. \& Fayyad, U. 1998. Refining initial points for k-means clustering. Proc. 15th International Conf. on Machine Learning.

Chandran, R.V., Jeyaram, A., Jayaraman, V., Manoj, S., Rajitha, K. \& Mukherjee, C.K. 2009. Prioritization of satellite derived potential fishery grounds: An analytical hierarchical approach-based model using spatial and non-spatial data. International Journal of Remote Sensing 30(17): 4479-4491.

Chassot, E., Bonhommeau, S., Reygondeau, G., Nieto, K., Polovina, J.J., Huret, M., Dulvy, N.K. \& Demarcq, H.
2011. Satellite remote sensing for an ecosystem approach to fisheries management. ICES Journal of Marine Science 68: 651-666.

Collette, B.B. \& Russo, J.L. 1984. Morphology, systematics and biology of the Spanish mackerels (Scomberomous, Scombridae). Fish Bulletin US 82: 545-692.

Fang, W. \& Fang, G. 1998. The recent progress in the study of the Southern South China Sea circulation. Advance in Earth Sciences 13(2): 166-172.

Frontier, S. 1976. Étude de la decroissance des valeurs propers dans une analyze en composantes principals comparison avec le modèle de baton brisé. J. Exp. Mar. Biol. Ecol. 25: 67-75.

Gambang, A.C., Ramli, H.B. \& Awang, D. 2003. Overview of biology and exploitation of the small pelagic fish resources of the EEZ of Sarawak, Malaysia. National Fisheries Symposium, Kota Bharu, Kelantan.

Grim, J., Novovicova, J., Pudil, P., Somol, P. \& Ferri, F. 1998. Initialization normal mixtures of densities. Proc. Int'l Conf. Pattern Recognition (ICPR 1998).

Guttman, L. 1954. A new approach to factor analysis: The radex. In Mathematical Thinking in the Social Sciences, edited by Lazarsfeld, P.F. Glencoe: The Free Press.

Jackson, D.A. 1993. Stopping rules in principal components analysis: A comparison of heuristical and statistical approaches. Ecology 74: 2204-2214.

Jolliffe, I.T. 1986. Principal Component Analysis. New York: Springer-Verlag.

Lanz, E., Manuel, N.M., Juana, L.M. \& Dworak, J.A. 2009. Small pelagic fish catches in the Gulf of California associated with sea surface temperature and chlorophyll. CalCOFI Report 50: $134-146$.

Laevastu, T. \& Hayes, M.L. 1981. Fisheries Oceanography and Ecology. Oxford: Fishing News.

Legendre, P. \& Legendre, L.F. 1998. Paper presented at the Numerical Ecology, Amsterdam, Netherlands.

Mansor, M. 1989. Tumbesaran, kematian dan corak pengrekrutan Ikan Kembung Rastrelliger kanagurta (Cuvier) di Pantai Barat Semenanjung Malaysia. Fisheries Bulletin 59 (Jabatan Perikanan: Kementerian Pertanian Malaysia). p. 22.

Mansor, M., Abdullah, S. \& Hamid, A. 1996. Population structure of small pelagic fisheries off the East Coast of Peninsular Malaysia. Fisheries Bulletin 99 (Jabatan Perikanan: Kementerian Pertanian Malaysia), 30.

MMD. 2016. Malaysian Meteorological Department. http://www. met.gov.my/web/metmalaysia/climate/generalinformation/ malaysia.

Mohsin, K.M. \& Mohamed, M.I. 1988. Ekspedisi Matahari' 87: A Study on the Offshore Waters of the Malaysian EEZ. Occasional Publication No. 8. Universiti Pertanian Malaysia.

Moore, A. 1998. Very fast em-based mixture model clustering using multiresolution kd-trees. Proc. Neural Info. Processing Systems (NIPS 1998).

Nishida, T., Miyashita, K. \& Lyne, H. 1999. Spatial dynamics of sothern bluefin tuna recruitment. Proceeding of the First International Symposium on GIS in Fishery Sciences, Seattle.

Nurdin, S., Mustapha, M.A., Lihan, T. \& Tangang, F. 2017a. Spatial and temporal variability of the chlorophyll- $a$ concentration in Makassar Strait using Empirical Orthogonal Function analysis of satellite images. Indian Journal of Geo Marine Sciences 46(07): 1381-1389.

Nurdin, S., Mustapha, M.A., Lihan, T. \& Zainuddin, M. 2017b. Applicability of remote sensing oceanographic data in the detection of potential fishing grounds of Rastrelliger 
kanagurta in the archipelagic waters of Spermonde, Indonesia. Fisheries Research 196: 1-12.

Nurdin, S., Mustapha, M.A. \& Lihan, T. 2014. The relationship between sea surface temperature and chlorophyll- $a$ concentration in fisheries aggregation area in the archipelagic waters of spermonde using satellite images. The 2013 UKM FST Postgraduate Colloquium, UKM.

Pena, H., Gonzalez, C. \& Vejar, F. 1999. Study of spatial dynamics of Jack Mackerel fishing grounds and environmental conditions using GIS. Proceeding of The First International Symposium on GIS in Fishery Sciences, Seattle.

Polovina, J.J.\& Howell, E.A. 2005. Ecosystem indicators derived from satellite remotely sensed oceanographic data for the North Pacific. ICES Journal of Marine Science 62: 31-27.

Rebert, J.P., Donguy, J.R., Elidin, G. \& Wyrtki, K. 1985. Relations between sea level, thermocline depth, heat content and dynamic height in the tropical Pacific Ocean. Journal Geophysical Research 90: C611719-C611725.

Shaari, N.R. \& Mustapha, M.A. 2018. Predicting potential Rastrelliger kanagurta fish habitat using MODIS data and GIS Modelling: A case study of Exclusive Economic Zone, Malaysia. Sains Malaysiana 47(7): 1369-1378.

Shaari, F. \& Mustapha, M.A. 2017. Factors influencing the distribution of Chl- $a$ along Coastal Waters of East Peninsular Malaysia. Sains Malaysiana 46(8): 1191-1200.

Skjoldal, H.R. 2004. Fish stocks and fisheries in relation to climate variability and exploitation natural resource system challenge: Ocean and aquatic ecosystem. In Encyclopedia of Life Supporting System (EOLSS), developed under the auspices of the UNESCO, Oxford, UK.

Solanki, H.U., Dwivedi, R.M., Nayak, S.R., Naik, S.K., John, M.E.\& Somvanshi, V.S. 2005. Cover: Application of remotely sensed closely coupled biological and physical process for marine fishery resources exploration. International Journal of Remote Sensing 26(10): 2029-2034.

Solanki, H.U., Dwivedi, R.M. \& Nayak, S.R. 2001. Synergistic analysis of SeaWiFS chlorophyll concentration and NOAAAVHRR SST features for exploring marine living resources. International Journal of Remote Sensing 22: 3877-3882.

Suhaila, J. \& Jemain, A.A. 2009. A comparison of the rainfall patterns between stations on the East and the West Coasts of Peninsular Malaysia using the smoothing model of rainfall amounts. Meteorol. Appl. 16(3): 391-401.

Susanto, R.D., Moore, T.S. \& Marra, J. 2006. Ocean color variability in the Indonesian seas during the SeaWiFS era. Geochem. Geophy. Geosy. 7(5): 1-16.

Tang, D.L. \& Kawamura, H. 2002. Ocean color monitoring of coastal environments in the Asian waters. Journal Korea Society Oceanography 37: 154-159.

Vasconcelos, R.P., Le Pape, O., Costa, M.J. \& Cabral, H.N. 2013. Predicting estuarine use patterns of juvenile fish with Generalized Linear Models. Estuar. Coast. Shelf Sci. 120: 64-74. http://dx.doi.org/10.1016/j.ecss.2013.01.018.

Wilson, C. 2011. The rocky road from research to operations for satellite ocean-color data in fishery management. ICES Journal of Marine Science 68(4): 677-686.

Wyrtki, K. 1961. Physical oceanography of the Southeast Asian waters. NAGA Report Vol. 2. Scientific Results of Marine Investigations of the South China Sea and the Gulf of Thailand 1959-1961. The University of California, Scripps Institution of Oceanography, La Jolla, California. pp. 1-195.
Xie, S.P., Xie, Q., Wang, D. \& Liu, W.T. 2003. Summer upwelling in the South China Sea and its role in regional climate variations. Journal of Geophysical Research 108(C8): 3261

Xian, T., Sun, L., Yang, Y. \& Fu, Y. 2012. Monsoon and eddy forcing of Chlorophyll- $a$ variation in the Northeast South China Sea. International Journal of Remote Sensing 33(23): 7431-7443.

Yahaya, N.A.Z., Musa, T.A., Omar, K.M., Din, A.H.M., Omar, A.H., Tugi, A. \& Wahab, M.I.A. 2016. Mean Sea Surface (MSS) Model determination for Malaysian Seas using MultiMission Satellite Altimeter. The International Archives of the Photogrammetry, Remote Sensing and Spatial Information Sciences. Volume XLII-4/W1. International Conference on Geomatic and Geospatial Technology (GGT). pp. 3-5.

Yanagi, T., Sachoemar, S.I., Takao, T. \& Fujiwara, S. 2001. Seasonal variation of stratification in the Gulf of Thailand. Journal of Oceanography 57: 461-470.

Yusop, S.M. \& Mustapha, M.A. 2019. Influence of oceanographic parameters on the seasonal potential fishing grounds of Rastrelliger kanagurta using maximum entropy models and remotely sensed data. Sains Malaysiana 48(2): 259-269.

Zagaglia, C.Z., Lorenzzetti, J.A. \& Stech, J.L. 2004. Remote sensing data and longline catches of yellowfin tuna (Thunnus albacares) in the equatorial Atlantic. Remote Sensing of Environment 93(1-2): 267-281.

Zainuddin, M. 2007. Mapping of potential fishing grounds of Rastrelliger kanagurta in Bantaeng waters, South Sulawesi. Jurnal Sains dan Teknologi 7(2): 57-64.

Zainuddin, M., Saitoh, K. \& Saitoh, S.I. 2008. Albacore (Thunnus alalunga) fishing ground in relation to oceanographic conditions in the western North Pacific Ocean using remotely sensed satellite data. Fisheries Oceanography 17(2): 61-73.

Zheng, X., Pierce, G.J. \& Reid, D.G. 2001. Spatial patterns of Whiting abundance in Scottish waters and relationship with environmental variables. Fisheries Research 50: 259-270.

Yeny Nadira, K. \& Mustapha, M.A.*

Centre for Earth Sciences and Environment

Faculty of Science and Technology

Universiti Kebangsaan Malaysia

43600 UKM Bangi, Selangor Darul Ehsan

Malaysia

Yeny Nadira, K. \& Ghaffar, M.A.

School of Fisheries and Aquaculture Sciences

Universiti Malaysia Terengganu

21300 Kuala Terengganu, Terengganu Darul Iman Malaysia

Mustapha, M.A.*

Institute of Climate Change

Universiti Kebangsaan Malaysia

43600 UKM Bangi, Selangor Darul Ehsan

Malaysia

*Corresponding author; email: muzz@ukm.edu.my

Received: 15 April 2019

Accepted: 15 August 2019 